sciendo Порівняльна професійна педагогіка 8(4)/2018 Comparative Professional Pedagogy 8(4)/2018

DOI: $10.2478 /$ rpp-2018-0051

$\mathrm{PhD}$ in PE and Sports Pedagogy, Assistant Professor,

ABDULLAH BORA ÖZKARA

Erzurum Technical University, Turkey

Address: ETÜ, SporBilimleriFakültesi, 25100-Yakutiye/Erzurum, Turkey

E-mail:boraozkara@gmail.com

\title{
COMPARATIVE RESEARCH ON INCLUSIVE EDUCATION IN ENGLAND, GERMANY, FRANCE AND TURKEY FROM THE PERSPECTIVE OF PHYSICAL ACTIVITY
}

\begin{abstract}
Different countries differently address the physical education needs of disabled children. Some focus only on the classroom learning hence equipping the children with little knowledge on physical education. Others lack the facilities to facilitate the physical education of the disabled. This has led to an increased number of the disabled with little or no knowledge about their talent in the field of sports. This paper compares access to the recreation and physical education by the disabled in England, Germany, France and Turkey. The countries were determined by taking into consideration the population and geographical conditions. Data is collected from secondary resources and compared for the countries. The paper also sheds light on the factors that hamper the provision of physical education to the disabled in the four countries. It is concluded that France's education system best addresses the special educational needs and the disabled are equipped with adequate physical knowledge. It is also found that lack of facilities for use by the disabled, education systems that do not recognize the physical educational needs of the disabled, and the negative belief that the disabled do not have a place in the field of sports are the factors that have been hampering the provision of physical education to the disabled children in the four countries.
\end{abstract}

Keywords: comparative inclusive education, disability and sports, physical activity.

\section{INTRODUCTION}

According to the Salamanca Statement, every child is entitled to the right to education (Kiru \& Cooc, 2018). The disabled children are not excluded from the statement. The Salamanca Statement further declares that the unique abilities, interests, learning needs, and characteristics of the children should be recognized in the provision of education to the children. This implies that the unique abilities and characteristics of the disabled children should be recognized so as to ensure that they have equal access to education just like the other children. The term education, as used in the Salamanca Statement, does not only refer to the basic subjects that are taught in school but also includes physical education and all the other subjects which equip students with knowledge and skills for use in addressing different problems in life (Winzer \& Mazurek, 2014). To fulfill the requirements of the statement, countries need to ensure that all the children, regardless of their uniqueness, have access to all subjects which are capable of equipping them with basic knowledge and skills for handling different problems in the future life. 
To ensure that even the disabled have access to education, some countries have focused on such basic subjects as Mathematics, English, Religious Education, technical subjects, and humanities (Pillay, Smit \& Loock, 2013). This is evident in the fact that there are schools for the disabled in the many parts of both the developed and developing countries. The teachers employed in these schools have specialized in special needs education. They end up using the best strategies in ensuring that the students have understood what is in the curriculum. Also, exams for disabled children are also set and examined by qualified individuals in the field (Engelbrecht, 2013). This is an indication that both the developed and the developing countries have tried to ensure that the disabled have equal access to education. However, there is one area where both the developing and developed countries have failed in the improvement of access to education by the disabled children. There have been little or no efforts, in both the developed and developing countries, to ensure that the disabled have had access to physical education (FernáNdezLóPez, et al., 2013). This is the reason behind the fact that very few countries across the world organize sports events for the disabled.

Just as it is argued for the case of non-disabled children, not all children are talented in education; there are also disabled children who are talented in football, running, playing table tennis, and other physical activities (Darling-Hammond, 2017). If the focus is only directed to the basic subjects, some children end up not recognizing their talents. Physical education is not only concerned with going out and doing exercises; it also involves the equipment of the students with the knowledge of movement so as to ensure that they are physically competent (Ennis, 2014). It is through the increased physical competence that the students end up recognizing what they are capable of doing hence entering the sport of their choice. For the students to develop the competence they should not only be taken out on the field and allowed to engage in different physical exercises; they should also be taught in class how the exercises are done and what one should do so as to become more active and physically fit. According to Altbach (2015), this is not done in many of the countries and hence an indication that the disabled children who are not good in education have not yet recognized their talents in the field of sports.

Different scholars have carried out research on the access to education by the disabled children in both the developed and the developing countries. As a result, sufficient information has been provided on the extents at which the different countries have gone in the effort to ensure that the basic right to education by the disabled children has been observed. Also, the challenges in both the developed and developing countries which reduce the ability of the available school to provide the best education to the disabled children have been provided (Schwab, et al., 2015).

\section{THE AIM OF THE STUDY}

The paper seeks to answer the questions below: 1. Currently, what is the state of access to physical education for disabled children in England, Germany, France and Turkey? 2. What are the potential barriers hampering access to physical education by the disabled children and hence poor performance in sports in these countries?

\section{THEORETICAL FRAMEWORK AND RESEARCH METHODS}

The method used in this research is a highly preferred document analysis and document analysis in comparative research. Document analysis covers the analysis of written materials containing information about the facts or facts intended to be investigated (Patton, 2002). All positive and negative criticisms about this method are accepted from the 
sciendo Порівняльна професійна педагогіка 8(4)/2018 Comparative Professional Pedagogy 8(4)/2018

beginning. Data was obtained from primarily related to education of the country's official webpage journal articles and reliable sources from reputable websites and research repositories. The online resources reflect information collected over the past 10 years, some with earlier references.

The rationale for comparing England, Germany, France and Turkey

England, Germany, and France are best known for football sports. However, they are not active in sports involving the disabled. For example, these countries have organized the best football leagues in the world. In England, they have the English Premier League which has most of the best football clubs in the world (Lechner\& Downward, 2017). In Germany, they have Bundesliga which is well funded and organized (Hoppe, et al., 2015). France has League 1 which has the most expensive players in the world such as Mbappe and Neymar. Under these major leagues, the countries have organized other competitions in not only football but such as fields as hockey, ice hockey, volleyball, rugby, and tennis (Scelles, et al., 2013). All these leagues involve non-disabled individuals. As for the Turkey it seems to be the most popular sport is football. But this interest also includes disabled football. Turkey's football federation particular show much interest in soccer with disabilities and share their facility. It can be said that there is a need for some more support for disabled people in terms of physical education and sports training. Comparison of access to physical education among the countries will help to identify the country which has been more reluctant in providing access to physical education by the disabled and the available barriers preventing full access to physical education which can be addressed to ensure that the disabled recognize their talents in the field of sports and progress to the same levels with the enabled students. As seen in Graph 1, it is seen that there are differences in the proportion of individuals with disabilities according to gender. Statistical data shared by the European Union and Turkish Statistical Institute reported that women's disability rates higher than men (Eurostat, 2017; Turkish Statistical Institute, 2011).

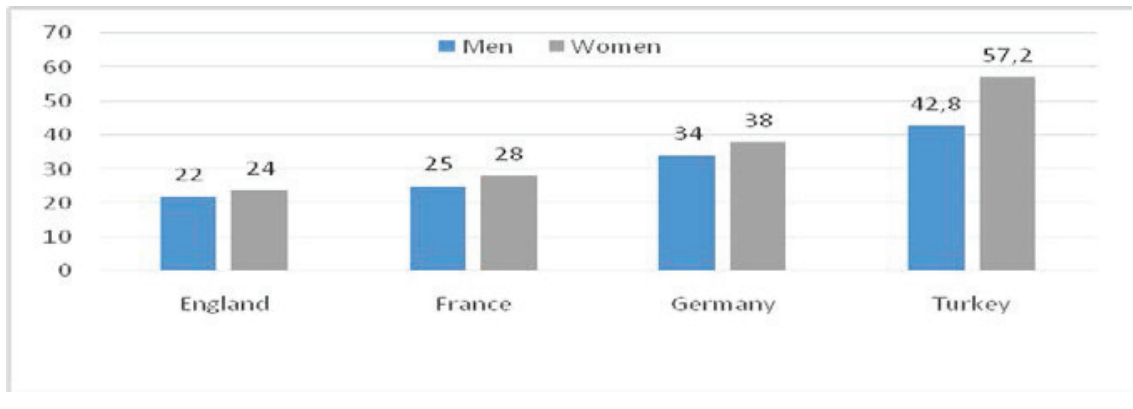

Fig. 1. Percent of people with disabilities by gender

In England, the government has been responsible for providing special needs education since the passing of the Universal Declaration of Human Rights in the year 1948 (Cook \& Odom, 2013). Since then, special education has been provided with the aim of enabling children in need of additional provision to make significant progress in their life. The children provided with the special needs education are those with severe or moderate difficulties of learning, sensory disabilities, neurological disabilities, physical disabilities, and any mental disabilities. Children who qualify for the provision of the special needs 
education have been provided with additional interventions of education. There have been waves 2 and 3 interventions where different areas of difficulties for the children have been focused within the classroom. Wave 3 intervention has been done with the aim of accelerating the disabled children's progress (Chowdry, et al., 2013). It is clear that the focus has been directed to the classroom work. Physical education among the disabled children has not been historically given emphasis in England and hence the reason behind the fact that the sports events for the disabled are not organized. The disabled students end up not recognizing their talents due to lack of knowledge, sports facilities, and the support is given to the non-disabled children (Eyles\& Machin, 2015).।

In history, Germany's education system has been focused on the production of employees with technical skills of the highest order (Reuter, et al., 2013). This has resulted in a situation whereby physical education is not given the priority it deserves for both the disabled and the non-disabled students. However, there are many private sports academies in the different major cities of the country. The academies have developed in the recent past providing most of the successful footballers in the history of the sport (Güllich, et al., 2014). However, none of the private academies in the history of Germany has ever enrolled a group of disabled children. The government has not so far filled the gap left. This has left the disabled children without an option of enrolling in an academy or school in which their talents can be identified and natured (Wedgwood, 2014). Germany has lagged behind in the provision of special needs education compared to England and France due to its huge focus on producing technically skilled students to take part in the manufacturing sector of the country.

France has excellently provided special needs education in the past decades (Ruffié, Ferez\& Lantz, 2014). Children with special educational needs have been recognized in the French education system. The government has established schools for the disabled in the different parts of the country where disabled children are provided with specialists for developing their competence. Even in the schools for the non-disabled children, the government has provided and has been maintaining the different facilities for the disabled hence putting the schools in the best position to accommodate some disabled students (Oller\&Glasman, 2013). However, the disabled students in these schools are not helped to achieve higher physical competence levels as more efforts are directed towards the helping of the non-disabled children. The students who enroll in the schools for the disabled have been equipped with education in all the areas. This has led to the production of physically competent children with enough knowledge about their talent and how they can develop it. According to Gispert (2014), in history, France has developed the best strategies for equipping disabled students with physical knowledge compared to Germany and England. This has been achieved through the recognition of the special educational needs in the French education system.

Turkey has begun a systematic way to support the education of individuals with special educational needs in early 1950 as a professional. Firstly, the idea that disabled individuals constitute a health problem has been avoided. It is accepted that disabled individuals are the subject of education. Then the responsibility of the disabled individuals was transferred from the Ministry of Health to the Ministry of National Education. Departments for the education of disabled individuals in universities have been established in Ankara the capital city of Turkey. In 2005 changes in the law are made about people with disabilities. The existing official structures of public institutions and organizations, all existing roads, pavement, pedestrian crossing, open and green areas and sports areas have 
been accepted as being obligatory for access to disabled people. The special education teaching department for disabled people has been in the faculties of education for many years in Turkey (Melekoğlu, 2014; Konar\&Yildiran, 2012). Physical education and sport activities for the disabled were used as a course in the departments until 2010. After 2010, the Turkish Higher Education Council established a separate department for physical education and sports teaching for the disabled.

Potential barriers hampering the access to P.E. by the disabled children

Education System

One of the factors behind the poor access to physical education by the disabled children in England and Germany is the education system. The education systems in these countries do not give a higher priority to the provision of special needs education (Freina\&Ott, 2015). In England, Universal Declaration of Human Rights of the year 1948 is taken into consideration when only making the decision on the role and responsibility of the government in the provision of the special needs education. The government takes it as a responsibility in the provision of special needs education. However, it only concentrates on the classroom work hence giving little concern to the physical education of the disabled children. In Germany, the education system is focused only on producing students who are technically fit to work in different manufacturing industries. France is the only country whose educational system is more focused on increasing the competence of disabled students (Quennerstedt\& Larsson, 2015). As for the education of disabled Turkey it has been neglected for many years. However, after the 2000s, the inclusion of people with disabilities was accelerated (During the term of President Erdogan's government). Physical facilities have been increased.

Lack of facilities

The French government has provided facilities in both the schools for the disabled and the ordinary schools. This provides a favorable educational environment for the disabled who end up identifying their talent and learning how to develop it. In Germany, the focus is more on the development of facilities for improving the technical skills for the disabled so as to make them capable of participating in the industry-based economy. This has helped developed technically skilled disabled students with little knowledge of physical education and who have no place in the field of sports (Hills, Dengel\&Lubans, 2015). In France, the government has provided adequate facilities for the disabled that help them identify and work on their talents.

Beliefs

Historically, it has been believed that the disabled have no place in the field of sports (Hoyle, 2018). This has led the different countries in the diversion of their focus to the development of disabled individuals capable of doing work on their own so as to earn for their living. It should be understood in the three countries that physical education enables students to identify their talents and the best ways in which they can improve it and be competitive even in sports organized for the disabled. Exercise and physical activity are important for the development of each individual as well as are important for the disabled.

RESULTS

Physical education is differently prioritized in Germany, France and England and Turkey. Each country has an important economic power in its region. Also, the proportion of disabled children in the school is low. This implies that the countries are capable to provide the best facilities for the disabled education so as to equip them with enough physical knowledge. Comparing the four countries, difficulties encountered in the rate of 
people with disabilities achieve their basic activities in Turkey is $60 \%$. In England, the rate of difficulty faced by people with disabilities in achieving basic activities is $25 \%$. Germany difficulties encountered in the rate of people with disabilities achieve their main activity is said to be a ratio of over $25 \%$. The difficulty in reaching the basic activities of persons with disabilities in France is reported to be around 20\% (European Commission, 2018). However, its government has channeled enough funds for use in the development of the special needs education (Kirkegaard, 2015). This has led to the establishment of institutions with enough facilities for use by the disabled in learning. As a result, the disabled are equipped with enough knowledge of physical education. In Germany, the focus is on the development of the individuals fit to work on the manufacturing industries hence having poor facilities for equipping the disabled with adequate physical knowledge. England focuses on the provision of the special needs education in a classroom setting. This has led to disabled children with little or no knowledge of physical education.

The education systems in Germany and England do not favor the provision of physical education to the disabled. Special educational needs are recognized in the French education system and hence the reason behind the increased number of disabled children majoring in sports. The second barrier to the provision of physical education to the disabled is the lack of facilities. In Germany, for example, there are inadequate facilities for use by disabled students while doing physical exercises (Kohl, 2015). In England, the focus is on classroom learning. It is only in France where the government has provided adequate equipment for use by the disabled during physical education classes (Ardoy, et al., 2014). In Turkey there is a need to further encouragement of participation in physical activity of people with disabilities Finally, there has been a belief that the disabled have no place in the field of sports hence leading to poor financing of the special needs education by the government.

\section{CONCLUSIONS}

France has been excellent in the provision of physical education to the disabled compared to Germany and England. As for Turkey do not yet see that people with disabilities are currently in the process of being included in social life. The work carried out after the 2000s should be continued by increasing. The English government is very active in the financing of the physical needs education but only focuses on classroom education rather than physical education. In Germany, the government emphasizes on the equipment of the disabled with technical skills so as to make them fit to work in the industry-based economy. Lack of facilities for use by the disabled, education systems that do not recognize the physical educational needs of the disabled, and the negative belief that the disabled do not have a place in the field of sports are the factors that have been hampering the provision of physical education to the disabled children in England, Germany, and France.

Further studies should be focused on the problem of inclusive education in Scandinavian countries.

\section{REFERENCES}

1. Altbach, P. (2015). Higher education and the WTO: Globalization run amok. International Higher Education, (23).

2. Ardoy, D. N., Fernández Rodríguez, J. M., Jiménez Pavón, D., Castillo, R., Ruiz, J. R., \& Ortega, F. B. (2014). A Physical Education trial improves adolescents' cognitive performance and academic achievement: the EDUFIT study. Scandinavian Journal Of Medicine \& Science In Sports, 24 (1), e52-e61 
sciendo Порівняльна професійна педагогіка 8(4)/2018 Comparative Professional Pedagogy 8(4)/2018

3. Chowdry, H., Crawford, C., Dearden, L., Goodman, A., \& Vignoles, A. (2013). Widening participation in higher education: analysis using linked administrative data. Journal of the Royal Statistical Society: Series A (Statistics in Society), 176 (2), 431-457.

4. Cook, B. G., \& Odom, S. L. (2013). Evidence-based practices and implementation science in special education. Exceptional children, 79 (2), 135-144.

5. Darling-Hammond, L. (2017). Teacher education around the world: What can we learn from international practice? European Journal of Teacher Education, 40 (3), 291-309.

6. Engelbrecht, P. (2013). Teacher education for inclusion, international perspectives.

7. European Agency for Special Needs and Inclusive Education. (2014). Retrieved from https://www.european-agency.org/

8. European Commission. (2018). Eurostat regional yearbook 2018 edition. Retrieved from https://doi.org/10.2785/231975.

9. Eyles, A., \& Machin, S. J. (2015). The introduction of academy schools to England's education.

10. FernáNdez-LóPez, Á.,RodríGuez-FóRtiz, M. J., RodríGuez-Almendros, M. L., \& MartíNez-Segura, M. J. (2013). Mobile learning technology based on iOS devices to support students with special education needs. Computers \& Education, 61, 77-90.

11. Freina, L., \& Ott, M. (2015). A literature review on immersive virtual reality in education: state of the art and perspectives. eLearning \& Software for Education, (1).

12. Gispert, H. (2014). Mathematics education in France: 1800-1980. In Handbook on the history of mathematics education (pp. 229-240). New York, NY: Springer.

13. Güllich, A. (2014). Selection, de-selection, and progression in German football talent promotion. European Journal of Sport Science, 14 (6), 530-537.

14. Hills, A. P., Dengel, D. R., \& Lubans, D. R. (2015). Supporting public health priorities: recommendations for physical education and physical activity promotion in schools. Progress in cardiovascular diseases, 57 (4), 368-374.

15. Hoppe, M. W., Slomka, M., Baumgart, C., Weber, H., \& Freiwald, J. (2015). Match running performance and success across a season in German Bundesliga soccer teams. International Journal of Sports Medicine, 36 (07), 563-566.

16. Hoyle, S. (2018). The witch and the detective: mid-Victorian stories and beliefs. In Witchcraft Continued. Manchester University Press

17. Kirkegaard, J. F. (2015). The true levels of government and social expenditures in advanced economies. Policy Brief, 15, 4.

18. Kiru, E., \&Cooc, N. (2017). A Comparative analysis of access to education for students with disabilities in Brazil, Canada, and South Africa. Journal of International Special Needs Education.

19. Kohl, S. (2015). The power of institutional legacies: how nineteenth-century housing associations shaped twentieth-century housing regime differences between Germany and the United States. European Journal of Sociology/Archives Européennes de Sociologie, 56 (2), 271-306.

20. Konar, N., \&Yildiran, İ. (2012). Engellileriçin Beden Eğitimive Spor Öğretmenliği: GereksinimveBir Program Modeli. SelçunUniversity ,journal Of Physical Education And Sports Science, 14 (2), 208-216.

21. Lang, T., \& Schoen, V. (2016). Food, the UK and the EU: Brexit or Bremain?

22. Lechner, M., \& Downward, P. (2017). Heterogeneous sports participation and labour market outcomes in England. Applied Economics, 49 (4), 335-348. 
23. Melekoğlu, M. A. (2014). Special education today in Turkey. Special Education International Perspectives: Practices Across the Globe, 28 (1), 529-557.

24. Oller, A. C., \&Glasman, D. (2013). Education as a market in France. In Private tutoring across the Mediterranean (pp. 77-91). Rotterdam: Sense Publishers.

25. Pillay, M. S., Smit, B., \& Loock, C. (2013). Policy disjuncture between the National Curriculum Statement and Curriculum 2005 training initiatives. International Journal of Multiple Research Approaches, 7 (1), 119-132.

26. Quennerstedt, M., \& Larsson, H. (2015). Learning movement cultures in physical education practice. Sport, Education and Society, 20 (5), 565-572.

27. Patton, M. Q. (1980). Qualitative research and evaluation methods. Book Qualitative Research and Evaluation Methods.

28. Reuter, M. A., Hudson, C., Van Schaik, A., Heiskanen, K., Meskers, C., \& Hagelüken, C. (2013). Metal recycling: Opportunities, limits, infrastructure. A Report of the Working Group on the Global Metal Flows to the International Resource Panel.

29. Ruffié, S., Ferez, S., \& Lantz, E. (2014). From the institutionalization of 'all disabilities' to comprehensive sports integration: France joining the Paralympic movement (1954-2012). The International Journal of the History of Sport, 31 (17), 2245-2265.

30. Scelles, N., Durand, C., Bonnal, L., Goyeau, D., \& Andreff, W. (2013). My team is in contention? Nice, I go to the stadium! Competitive intensity in the French football Ligue 1. Economics Bulletin, 33 (3), 2365-2378.

31. Schwab, S., Gebhardt, M., Krammer, M., \& Gasteiger-Klicpera, B. (2015). Linking self-rated social inclusion to social behavior. An empirical study of students with and without special education needs in secondary schools. European Journal of Special Needs Education, 30 (1), 1-14.

32. Wedgwood, N. (2014). Hahn versus Guttmann: Revisiting 'Sports and the Political Movement of Disabled Persons'. Disability \& Society, 29 (1), 129-142.

33. Winzer, M., \& Mazurek, K. (2014). The Convention on the Rights of Persons with Disabilities: Notes on genealogy and prospects. Journal of International Special Needs Education, 17 (1), 3-12.

34. World Bank. (2017). World bank open data. Retrieved from https://data. worldbank.org/. 